\title{
AN IDENTIFICATION OF PHYSICS PRE-SERVICE TEACHERS' SCIENCE PROCESS SKILLS THROUGH SCIENCE PROCESS SKILLS-BASED PRACTICUM GUIDEBOOK
}

\author{
Darmaji*1, Dwi Agus Kurniawan $^{2}$, Ai Suryani ${ }^{3}$, Ayu Lestari ${ }^{4}$ \\ ${ }_{1,2,3,4}$ Physics Study Program of Education and Teacher Training Faculty, Jambi University \\ Jl. Lintas Jambi- Muaro Bulian, Muaro Jambi, Jambi, Indonesia. \\ *Correspondence address: Darmaji@unja.ac.id
}

Received: June $14^{\text {th }}, 2018$. Accepted: October $12^{\text {nd }}, 2018$. Published: October $29^{\text {th }}, 2018$

\begin{abstract}
This research was conducted to identify the science process skills of the physics education students of Jambi University in prism refraction practicum after using the basic physics practicum guidebook II. This research is a quantitative descriptive method. The study was conducted with a sample of 91 students. Data collection techniques were carried out using a science process skill observation sheet which was supported by interviews and documentation. Data were analyzed using descriptive statistics. The results showed that most students are highly skilled in implementing science process skills-based practicum with the following percentages: observing by $48.35 \%$, classifying by $38.46 \%$, measuring by $39.56 \%$, predicting by $58.64 \%$, compiling data tables by $51.65 \%$, making graph by $58.24 \%$, planning the experiment by $61.54 \%$, and conducting the experiment by $45.05 \%$. The students were also quite skilled in constructing hypotheses and defining variables with the percentage of $57.14 \%$ and $39.56 \%$, respectively. The results of the study are expected to be used as a consideration for study programs and other faculties at Jambi University as well as other universities to conduct related studies.
\end{abstract}

(C) 2018 Physics Education, UIN Raden Intan Lampung, Indonesia.

Keywords: physics education students, practicum, science process skills

\section{INTRODUCTION}

The success of the learning process is influenced by the quality and way of teaching a teacher. Quality teachers not only have knowledge but also have skills. One of the skills a teacher must possess is science process skills. According to (Mutisya, Rotich, \& Rotich, 2013), a teacher must have science process skills. It is a skill used by scientists when conducting scientific investigations (Lindrawati \& Rohandi, 2015).

Science process skills can be developed by conducting practical activities. In developing process skills, practicum methods can be used. Practicum activities can be used as activities to improve or develop students' scientific skills including psychomotor aspects (Deviyanti, Ashari, \& Kurniawan, 2016). In order for the practicum to be carried out to be effective in developing students' science process skills, a practicum guide is needed that can support the students' science process skills (Misbah, Mustikawati, M. Feyzarrif'at, 2018).

Science process skills serve to encourage students to develop the knowledge they have received (Idiege, Joseph, Nja, Cecilia, Ugwu, \& N3, 2017). Science process skills consist of basic science process skills and integrated process skills (Agustina \& Saputra, 2016). The basic and integrated process skills are very relevant and in accordance with science subjects in secondary schools (Jack, 2013).

Science process skills of a pre-service physics teacher are required to support learning activities. According to (Lindrawati \& Rohandi, 2015), Science process skills should be owned by preservice physics teachers, so that when they are becoming a real teacher, they can have an adequate understanding of science process skills and be able to apply it in the 
activities of learning in the classroom. If the physics teacher does not have the science process skills, then the teacher will not be able to develop the student's science process skills. In addition, learning will tend to be passive and students cannot construct their knowledge independently.

Considering the urgency of mastering the science process skills for physics education students, the Physics Education Study Program of Jambi University has developed a science process skills-based Basic Physics II practicum guidebook. Therefore, the researchers are interested in conducting research to find out basic science process skills and integrated science process skills of the pre-service physics teacher at the University of Jambi.
The difference in this research with previous research conducted by (Sari \& Zulfadewina, 2018) is the subject of this research and the description of science process skills seen after students use the scientific process skills-based practicum guidebook.

\section{METHOD}

This research employs a quantitative descriptive method. "Descriptive research on quantitative research involves a careful description of educational phenomena" (Gall, Gall, \& Borg, 2003)

Following is the research graph in Figure 1, and the research design in Table 1 ,

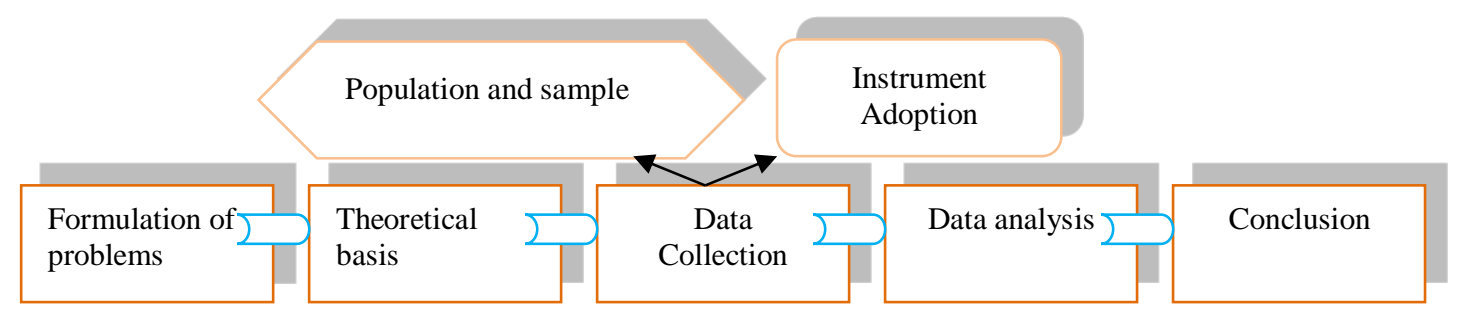

Figure 1. Modified Research Graph from Sugiyono 2014

Table 1 Research Plan

\begin{tabular}{ccc}
\hline Class & Treatment & Post-test \\
\hline Experimental & Science & Observation \\
& $\begin{array}{c}\text { Process Skills- } \\
\text { based }\end{array}$ & \\
& practicum & \\
& guidebook & \\
\hline
\end{tabular}

Based on Table 1, the students were given practicum guidebook based on science process skills, and then they were observed. In this study the sample used was less than 100, according to (Sugiyono, 2013) the data collection technique is suitable to use if the sample to be studied is less than 100 people, then total sampling technique can be used. The number of samples was 91 physics education students who took basic physics courses II.

The data collecting technique used was observed using the Observation Sheet instrument. An effective observation sheet is used to measure the science process skills (Nasrodin, Hindarto, \& E, Supeni, 2015). Observation sheet was made to refer to the observed indicators, including observing, classifying, measuring, predicting, compiling data tables, making hypotheses, making graphs, defining variables, conducting experiments, and designing experiments.

Students' science process skills data were analyzed through descriptive statistics using SPSS. Then to find out the mastery of science process skills, the students were grouped into four categories, as shown in Table 2.

Table 2. Students' science process skills mastery scale

\begin{tabular}{ccc}
\multicolumn{2}{c}{ scale } & \\
\hline No & Interval & Category \\
\hline 1 & $25,00 \leq \mathrm{x} \leq 43,75$ & Poor \\
2 & $43,75<\mathrm{x} \leq 62,50$ & Low \\
3 & $62,50<\mathrm{x} \leq 81,25$ & High \\
4 & $81,25<\mathrm{x} \leq 100,00$ & Excellent
\end{tabular}

Description: $\mathrm{x}=$ Mastery score of science process skills. 


\section{RESULTS AND DISCUSSION Results}

The results of the descriptive analysis of the data gathered on the science process skills-based practicum guidebook on prism refraction material shown are shown in Table 3, and the distribution of the mastery is shown in Table 4.

Table 3. Descriptive Analysis of Basic Science Process Skills

\begin{tabular}{lcc}
\hline \multicolumn{1}{c}{ Indicators } & Mean & Std. Deviation \\
\hline Observing & 78,44 & 18,58 \\
Classifying & 76,09 & 22,02 \\
Measuring & 72,12 & 20,33 \\
Predicting & 77,60 & 29,84 \\
\hline
\end{tabular}

Based on table 3, it is known that observing aspect has the highest average score with an average score and standard deviations respectively: 78.44 and 18.58 . The indicator that has the smallest average score is measuring with an average score of 72.12 and std deviation of 20.33 . Students' science process skills distribution is divided into four categories, poor, low, high, and excellent.

Table 4. Distribution of the Basic Science Process Skills

\begin{tabular}{lcc}
\hline Indicators & Category & Percentage \\
\hline Observing & Poor & 6,59 \\
& Low & 9,89 \\
& High & 35,16 \\
& Excellent & 48,35 \\
Classifying & Poor & 8,79 \\
& Low & 19,78 \\
& High & 32,97 \\
& Excellent & 38,46 \\
Measuring & Poor & 9,89 \\
& Low & 19,78 \\
& High & 30,77 \\
& Excellent & 39,56 \\
Predicting & Poor & 20,88 \\
& Low & 4,40 \\
& High & 16,48 \\
& Excellent & 58,24 \\
\hline
\end{tabular}

Based on Table 4 it is known that the basic science process skills have already mastered by students. This is known from the average score mastery of the science process skills for each indicator in all categories are all excellent. Predicting is an indicator that is mastered by students with a percentage of $58.24 \%$.

Table 5. Descriptive Analysis of Science Process Skills Data Integration

\begin{tabular}{lcc}
\hline \multicolumn{1}{c}{ Indicators } & Mean & Std. Deviation \\
\hline $\begin{array}{l}\text { Compiling data } \\
\text { table }\end{array}$ & 78,19 & 29,48 \\
$\begin{array}{l}\text { Making graphs } \\
\text { Collecting and } \\
\text { processing data }\end{array}$ & 86,26 & 20,16 \\
$\begin{array}{l}\text { Making } \\
\text { hypothesis }\end{array}$ & 70,14 & 15,81 \\
$\begin{array}{l}\text { Planning an } \\
\text { experiment }\end{array}$ & 81,41 & 21,87 \\
$\begin{array}{l}\text { Conducting an } \\
\text { experiment }\end{array}$ & 77,68 & 17,26 \\
\hline
\end{tabular}

Based on Table 5, it is known that the indicator of making graphs has the highest average score of 86.26 and std. deviation of 20.16. While obtaining and processing data is an indicator that has the smallest average score of 70.14 and std. deviation of 15.81 .

Table 6. Distribution of Integrated Science Process Skills

\begin{tabular}{lcc}
\hline Indicators & Category & Percentage \\
\hline Compiling data & Poor & 4,40 \\
table & Low & 13,19 \\
& High & 30,77 \\
& Excellent & 51,65 \\
Making graphs & Poor & 6,59 \\
& Low & 0,00 \\
& High & 35,16 \\
& Excellent & 58,24 \\
Making & Poor & 10,99 \\
hypothesis & Low & 3,30 \\
& High & 57,14 \\
& Excellent & 28,57 \\
Defining & Poor & 6,59 \\
Variable & Low & 31,87 \\
& High & 39,56 \\
Planning an & Excellent & 21,98 \\
experiment & Poor & 5,49 \\
& Low & 4,40 \\
& High & 28,57 \\
Conducting an & Excellent & 61,54 \\
experiment & Poor & 7,69 \\
& Low & 13,19 \\
& High & 34,07 \\
& Excellent & 45,05 \\
\hline
\end{tabular}


Based on Table 6, it is known that the indicator of making a hypothesis and defining variables are categorized as high while four other indicators are categorized as excellent. The indicator that is mastered by the students is planning experiments with an average percentage of $61.54 \%$.

\section{Discussion}

Observation is the main skill of all science process skills aspects so it must be mastered first to be able to master the other (Puspita, Sicilia, 2016). In this study, the observing skill is highly mastered by the students with a percentage of $48.35 \%$ and an average score of 78.44. Observation activities were carried out by students directly when the practicum takes place and indirectly by observing the images contained in the guidebook.

Students have a very good skill of classifying with a mastery percentage of $38.48 \%$ and an average score of 76.09 . Classifying skill is a skill often carried out by students so it is not difficult for them to master this skill well (Rahman, 2017). Classifying is the ability to identify similarities and differences in various observed objects (Sani, 2016). Classification activities carried out by students included grouping the same or opposite quantities, such as classifying the angle of deviation (D), the angle of incoming light (i), and the angle of refraction $(r)$.

Measuring is the second basic skill that must be mastered. This is because after students observed the tool and how to use the tool, they will begin to take measurements. Measuring is an activity that requires students to use a measuring tool and require students to do calculations to determine the measurement results (Rauf, Rasul, Mansor, Othman, \& Lyndon, 2013). Based on the result of the analysis, the students have an excellent skill in measuring with a percentage of mastery of $39.56 \%$ and an average score of 72.12. Based on the results of observations, students in addition to making measurements in a structured manner they also did it carefully. Science process skills make the students more careful in carrying out experiments and interested in what is done (Ambarsari, Santosa, \& Maridi, 2013).

The next science process skill mastered by the students is predicting with a percentage of $58.24 \%$ and an average score of 77.60. Predicting is to anticipate the consequences of a new situation or change past experience and previous observations (Wiwin \& Kustijono, 2018). In this study, predictions were made before students conducted experiments so that they had were not influenced by previous experiments. Science process skills-based learning requires students to have good initial knowledge (Deta, Suparmi, \& Widha, 2013). Based on the results of interviews with several students, information was obtained based on the identification of variables/laws related to the experiment. "... I make predictions based on the identification of existing formulated variables and based on refraction law ..." (interview conducted on 2 May 2018).

In general, physics education students have mastered basic science process skills well. These results identify that the use of practicum guidebook effectively increases the students' science process skills mastery. In accordance with the results of the research conducted by (Sari \& Zulfadewina, 2018), mastery of basic science process skills without using a science process skills-based practicum guidebook is still in the fairly good category.

Basic science process skills are skills that must be mastered by every student. Science and non-science require basic scientific process skills (Akinbobola \& Afolabi, 2010). Students of pre-service physics teacher who do not have basic science process skills will have difficulty in developing their knowledge. Mastery of 
science process skills can affect the mastery of concepts in the cognitive domain (Desstya, 2015). In addition, students who do not master basic science process skills will not master the integrated science process skills. Integrated process skills can be obtained after basic skills are mastered by students (Rauf et al., 2013).

Science process skills can make students more literate about science, according to the statement (Espinosa, Monterola, \& Punzalan, 2013) science process skills make students more knowledgeable in science. Students who have science process skills will have a positive attitude towards science and will also help them improve their scientific literacy. When students carry out scientific investigations, science process skills can also help in constructing the knowledge acquired during the activities.

Integrated science process skills are obtained after mastering basic science process skills. In this study, integrated science process skills were analyzed, namely on the making graphics, making hypotheses, compiling data tables, defining variables, planning experiments and conducting experiments aspects.

The compiling data table indicator from 91 physics students of Jambi University shows that they are excellent on this indicator with a percentage of $51.65 \%$. The students are also doing an excellent job in the making graphs indicator with a percentage of $58.24 \%$. This is certainly a good thing for a physics teacher candidate because making and understanding graphics is a basic ability for a scientist.

The hypothesis is a statement based on assumptions and has not been proven. Usually, hypotheses are used in determining theory and law. According to (İdris \& Halil, 2016), The Hypothesis is a statement based on assumptions whose truth has not been proven. The making hypotheses indicator reveal that the students are skilled in making experimental hypotheses with a percentage of $57.14 \%$.

The next indicator is defining variables. It can be seen that $39.56 \%$ of the students are skilled in identifying variables in the practicum. So, in this indicator, the students have been able to identify the dependent variable, the independent variable, and the control variable in the experiment. According to (Dönmez \& Azizoğlu, 2010), identifying variables is to see changes in variables that are related to other variables. For the planning, an experiment indicator, $61.54 \%$ of students belong to the excellent category in planning practicum activities.

The next indicator, which is conducting experiments, according to (Rezba et al., 1995) states that experiments include using the materials needed to create a mechanism that matches the practicum objectives, changes and control variables to reach data, record and evaluate data to analyze it, draw conclusions and provide reports on experiments conducted. The students are in the excellent category for the conducting experiments indicator with a percentage of $45.05 \%$. This is because based on the results of an interview; the students are able to carry out practical activities well by just following the instructions in the practicum guidebook used.

The results of this study are expected to be used as a consideration in broadly applying practicum guidebook based on science process skills, especially in physics education study programs.

\section{CONCLUSION AND SUGGESTION}

Based on the results of the study, the implementation of science process skillsbased Basic Physics II on prism refraction material can increase the basic science process skills and the integrated science process skills of physics education students of Jambi University. The most prominent basic science process skills are prediction with a percentage of $58.40 \%$, 
while the most prominent integrated science process skills are planning an experiment with a percentage of $61.54 \%$.

The researchers suggest further research on the relationship of mastery of science process skills with the mastery of physics concepts, creative thinking skills, and problem-solving skills.

\section{REFERENCES}

Agustina, P., \& Saputra, A. (2016). Analisis Keterampilan Proses Sains (KPS) Dasar Mahasiswa Calon Guru Biologi Pada Matakuliah Anatomi Tumbuhan (Studi Kasus Mahasiswa Prodi Pendidikan Biologi FKIP UMS). Seminar Nasional Pendidikn Sains, 71-78.

Akinbobola, A. O., \& Afolabi, F. (2010). Analysis of Science Process Skills in West African Senior Secondary School Certificate Physics. American-Eurasian Journal of Scientific Research, 4(5), 234-240.

Ambarsari, W., Santosa, S., \& Maridi. (2013). Penerapan Pembelajaran Inkuiri Terbimbing Terhadap Keterampilan Proses Sains Dasar Pada Pelajaran Biologi Siswa Kelas VIII SMP Negeri 7 Surakarta. Jurnal Pendidikan Biologi, 5(1), 81-95.

Deta, U. A., Suparmi, \& Widha, S. (2013). Pengaruh Metode Inkuiri Terbimbing Dan Proyek, Kreativitas, Serta Keterampilan Proses Sains Terhadap Prestasi Belajar Siswa. Jurnal Pendidikan Fisika Indonesia (Indonesian Journal of Physics Education), 9(1), 28-34. https://doi.org/10.15294/jpfi.v9i1.25 77

Deviyanti, L., Ashari, \& Kurniawan, E. S. (2016). Pengembangan Panduan Praktikum Fisika Berbasis Research Based Learning untuk Mengoptimalkan Domain Kognitif dan Psikomotorik Siswa di SMA Negeri 5 Purworejo, 9(2), 43-48.

Dönmez, F., \& Azizoğlu, N. (2010).
Investigation of the Students' Science Process Skill Levels in Vocational Schools: A case of Balikesir. Necatibey Faculty of Education Electronic Journal of Science and Mathematics Education, 4(2), 79109.

Espinosa, A. A., Monterola, S. L. C., \& Punzalan, A. E. (2013). CareerOriented Performance Tasks in Chemistry: Effects on Students' Critical Thinking Skills. Education Research International, 2013, 1-10. https://doi.org/10.1155/2013/834584

Gall, M. D., Gall, J. P., \& Borg, W. R. (2003). Educational Research An Introduction. Boston: Pearson Education.

Idiege, Joseph, K., Nja, Cecilia, O., Ugwu, \& N3, A. (2017). Development of Science Process Skills among Nigerian Secondary School Science Students and Pupils: An Opinion, 1(2), 13-21.

İdris, D., \& Halil, K. (2016). Determination of Prospective Preschool Teachers' Science Process Skills. Journal of European Education, 6(1), 32-42. https://doi.org/10.18656/jee.65104

Jack, G. U. (2013). The Influence of Identified Student and School Variables on Students 'Science Process Skills Acquisition. Journal of Education and Practice, 4(5), 16-23.

Lindrawati, B., \& Rohandi. (2015). Keterampilan Proses Sains Calon Guru Fisika, (April), 2013-2016.

Misbah, Mustikawati, M. Feyzarrif'at, M. D. P. (2018). Pengembangan Penunjuk Praktikum Fisika dasar I Berbasis 5M untuk Melatih Keterampilan Proses sains dan karakter WASAKA. Jurnal Fisika FLUX, 15(1), 26-29.

Mutisya, S. M., Rotich, S., \& Rotich, P. K. (2013). Conceptual Understanding of Science Process Skills and Gender Stereotyping : a Critical Component 
for Inquiry Teaching of Science in Kenya' S Primary Schools. Asian Journal of Social Sciences and Humanities, 2(3), 359-369.

Nasrodin, Hindarto, N., \& E, Supeni, S. (2015). Analisi Kebiasaan Bekerja Ilmiah Mahasiswa Fisika Pada Pembelajaran Mata Kuliah Praktikum Fisika Dasar, 4(1), 1-6.

Puspita, Sicilia, A. (2016). Dalam Lks Biologi Kelas X Yang Digunakan Oleh Siswa Man Di Kota Yogyakarta the Analysis of Science Process Skills Developed in Lks Biology Class X, 5(1), 30-39.

Rauf, R. A. A., Rasul, M. S., Mansor, A. N., Othman, Z., \& Lyndon, N. (2013). Inculcation of science process skills in a science classroom. Asian Social Science, $\quad 9(8), \quad 47-57$. https://doi.org/10.5539/ass.v9n8p47

Rezba, Spragule, Fiel, Funk, Okey, \& Jaus. (1995). Learning and Assessing Science Process Skill. Dubuque, IA: Kendall/Hunt Publishing Company.

Sari, P. M., \& Zulfadewina. (2018). Profil Penguasaan keterampilan Proses Sains Mahasiswa program Studi Pendidikan Guru Sekolah dasar. Jurnal Inovasi Pendidikan Dasar, 3(2), 65-72.

Sugiyono. (2013). metode penelitian kuantitatif, kualitatif dan $R \& D$. Bandung: Alfabeta.

Wiwin, E., \& Kustijono, R. (2018). The use of physics practicum to train science process skills and its effect on scientific attitude of vocational high school students. Journal of Physics; Conference Series, 997 (1), 1-9. 